\title{
The JIBS 2019 Decade Award: The Uppsala internationalization process model revisited: From liability of foreignness to liability of outsidership
}

\author{
Alain Verbeke \\ University of Calgary, Calgary, Canada; University \\ of Reading, Reading, UK; Vrije Universiteit Brussel, \\ Brussels, Belgium \\ Correspondence: \\ A Verbeke, University of Calgary, Calgary, \\ Canada \\ e-mail: alain.verbeke@haskayne.ucalgary.ca
}

Journal of International Business Studies (2020) 51, I-3. https://doi.org/10.1057/s41267-019-00292-y

The Selection Committee for the JIBS Decade Award was pleased to recommend the presentation of the 2019 JIBS Decade Award, recognizing the most influential article published in JIBS 10 years ago, to Jan Johanson and Jan-Erik Vahlne for their 2009 article, "The Uppsala internationalization process model revisited: From liability of foreignness to liability of outsidership" (JIBS, 40(9): 1411-1431).

The award, sponsored by JIBS' publisher Palgrave Macmillan, is designed to recognize the most influential paper published in JIBS 10 years prior and is presented at the annual AIB conference. In order to be considered for the JIBS Decade Award, an article must be one of the five most cited articles published in JIBS for the year being considered.

The 2019 Selection Committee members were Nicole Coviello (Chair, Wilfrid Laurier University, Canada), the current AIB Program Chair (Maria Tereza Fleury, Escola de Administracão de Empresas de São Paulo, Brazil) and immediate past AIB Program Chair (J.T. Li, Hong Kong University of Science and Technology). JIBS Editor-in-Chief Alain Verbeke was an ex officio, non-voting committee member. The Selection Committee examined total citations, total number of journals citing the paper, and total number of leading journals (excluding JIBS) citing the paper to determine the top five most cited articles. The Committee read and discussed the top five nominees and then voted on the winning article.

In recommending the award-winning article, the Committee noted that: "Johanson and Vahlne (2009) offer a timely reflection on how the research frontiers of international business have changed since publication of their seminal 1977 article. This leads 
them to thoughtfully reconsider their original arguments, noting if and how their initial assumptions - based on a study of Swedish-owned subsidiaries abroad- require updating. In so doing, Johanson and Vahlne demonstrate an important characteristic of strong scholarship: the willingness and ability of scholars to move forward from early contributions to acknowledge and incorporate new insights that emerged with the passage of time.

"Johanson and Vahlne's 2009 paper has substantially impacted research within and outside international business. It is used by researchers publishing in marketing, strategy, entrepreneurship, management, small business management, family business, and innovation management (among others).

"The 2009 paper revisits the 1997 Uppsala model by exploring developments in a number of literatures parallel to, yet part of, international business research. First, Johanson and Vahlne reposition the Uppsala model to acknowledge research from marketing on business networks. They view business networks as a market structure in which 'the internationalizing firm is embedded'. This perspective highlights the key role of interaction between actors in international markets; interaction that leads to socially constructed international business relationships based on reciprocal commitment, learning, and trust. This is a key point of differentiation from more traditional economic theory that defines a firm without reference to other firms. Also notable is Johanson and Vahlne's effort to articulate the concepts of network 'insidership' and 'outsidership', and the resultant implications for internationalizing firms.

"Second, Johanson and Vahlne incorporate arguments central to entrepreneurship research. They argue that opportunity development is a process similar to those of internationalization and relationship development. In the 2009 model, opportunities are considered to be the core element of knowledge that drives internationalization, with internationalization being pursued within a network. They also note the potential overlaps between effectuation logic and internationalization, including the centrality of individual actors and their characteristics (the latter being implied in the 2009 model).

"For all these reasons, the selection committee recommends the Johanson and Vahlne (2009) paper, which has become a widely cited and highly impactful article, for the 2019 JIBS Decade Award."
Importantly, Johanson and Vahlne's (2009) paper represented a significant step towards integrating several streams of thinking in international business scholarship. For example, the concept of outsidership is closely related to Hennart's (2009) perspective on the need to move away from MNEcentric analyses of international entry. Hennart highlighted the importance of complementary resources in host countries that may not be easily accessible in open markets. The presence of outsidership is also consistent with Rugman and Verbeke's (1992) and Verbeke's (2007) focus on the need to establish linkages with host country economic actors who control complementary resources, when some of the multinational enterprise's firm-specific advantages are location-bound, rather than non-location bound (the latter concept meaning: easily transferable, deployable and profitably exploitable across borders).

The process of overcoming outsidership precisely reflects the resource recombination activities needed to become successful in foreign markets. In this realm, Johanson and Vahlne (2009) provided a helicopter view on the resource recombination challenges at hand. But in-depth study is then still required of actual, focused resource recombination efforts, including informal exchanges such as trading favors, formal purchasing and distribution agreements, joint ventures, mergers and acquisitions, etc. A firm does not transform from being an outsider into an insider simply with the passing of time or through generic 'insiderization' processes. Insiderization requires strong selectivity in identifying complementary resources needed for success (including those related to bridging social capital, reputation building, securing institutional support, etc.). The preferred governance forms of international expansion in specific locations will typically be determined by the capacity of the various feasible governance alternatives associated with requisite resource recombination, to economize on bounded rationality and bounded reliability, and to contribute to value creation within particular time frames (Verbeke \& Kenworthy, 2008). If various resource recombination processes are at play simultaneously, entry mode mixes may be selected, even within a single location (Benito, Petersen \& Welch, 2009).

At the AIB Annual Meeting in Copenhagen, Denmark, in June 2019, Professor Vahlne, along with invited discussants Maria Tereza Fleury (FGV EAESP) and JT Li (HKUST), Nicole Coviello (Wilfrid 
Laurier University), and Tomas Hult (Michigan State University), made a retrospective presentation of the work and discussed where the field has progressed and where it should go next in positioning and applying the Uppsala model. When accepting the Decade Award, Jan-Erik Vahlne was joined on the stage by Martin Johanson. Martin is Jan Johanson's son, and a professor in the Department of Business Studies at Uppsala University, Sweden.

\section{REFERENCES}

Benito, G. R. G., Petersen, B., \& Welch, L. S. 2009. Towards more realistic conceptualisations of foreign operation modes. Journal of International Business Studies, 40(9): 1455-1470.

Hennart, J. F. 2009. Down with MNE-centric theories! Market entry and expansion as the bundling of MNE and local assets. Journal of International Business Studies, 40(9): 1432-1454.

Johanson, J., \& Vahlne, J.-E. 2009. The Uppsala internationalization process model revisited: From liability of foreignness to liability of outsidership. Journal of International Business Studies, 40(9): 1411-1431.

Rugman, A. M., \& Verbeke, A. 1992. A note on the transnational solution and the transaction cost theory of multinational
What follows in this issue are the authors' written Retrospective, together with the discussants' and co-authors' Commentaries, based on that AIB 2019 session. For the original 2009 article, please visit www.jibs.net, where it is available to download, along with all other past Decade Award winners.

strategic management. Journal of International Business Studies, 23(4): 761-771.

Verbeke, A. 2007. International business strategy. Cambridge: Cambridge University Press.

Verbeke, A., \& Kenworthy, T. P. 2008. Multidivisional vs metanational governance of the multinational enterprise. Journal of International Business Studies, 39(6): 940-956.

Publisher's Note Springer Nature remains neutral with regard to jurisdictional claims in published maps and institutional affiliations. 